\title{
Internet Use and Firms' Exports: Empirical Findings Based on Chinese Enterprise Survey Data
}

\author{
Min Wang \\ School of Economics, Central University of Finance and Economics \\ 39 South College Road, Haidian District, Beijing, China \\ Zip code: 100081 \\ Fang Li \\ Beijing Research Center of Urban Systems Engineering \\ No. 16, Xizhimen South Street, Xicheng District, Beijing, China \\ Zip code: 100035
}

\begin{abstract}
:
Using data from the World Bank's EnterpriseSurvey, thisempirical study identifies the effects of Internet use onexport frequency and intensity of firms in China. The results show that Internet use has a positive effect on the probability and intensity of enterprise export. In order to test the robustness of this result, this paper changes the construction method of the core explanatory variable, and finds that Internet use still plays a significant role in promoting the export of enterprises. Further, in view of the possible endogeneity problems caused by selection bias, this paper uses the balanced samples of propensity score matching(PSM) method for regression analysis, and the results are still robust. Finally, we find that firms with high capacity are more likely both toenter export markets and to be export intensive.
\end{abstract}

Key words: Internet use, Export of enterprises, Enterprise capacity

\section{Introduction}

In recent years, the Internet has been developing rapidly in China. According to the 44th statistical report on Internet development by China Internet network information center (CNNIC), the number of Internet users in China has reached 854 million and the Internet penetration rate has reached $61.2 \%$ by June 2019. The rapid popularization of the Internet provides a new, convenient and efficient information exchange channel for individuals and enterprises, which greatly reduces the cost of information exchange.Chinese internet-based economic activities are also showing a trend of rapid growth. According to the data of the general administration of customs, the total value of cross-border ecommerce imports and exports approved by customs in 2018 reached 134.7 billion yuan, up 50.0\% year on year. It can be seenfrom the above data that rapid development of Internet is playing an increasingly important role in international trade.However, we cannot infer the relationship between Internet use and the export of enterprises only by the macro data. We believe that it is necessary to conduct detailed analysis and discussion on this issue from the micro level.

In terms of the possible impact of the Internet on corporate exports, Anderson \&Wincoop (2004) argue that search cost and communication cost are two important and widespread forms of trade costs. And Venables(2001) points out that Internet can reduce the cost of organization management, search, match and communication between enterprises and upstream and downstream suppliers, as well as between enterprises and consumers. Therefore, it can be inferred that Internet can promote the export of enterprises by reducing the cost of trade search and communication. The objective of this study is toexplore whether Internet use has an impact on the export of enterprises.

Using firm-level data from the World Bank's Enterprise Survey database, whichcovers 2848 enterprises in China, this paper finds that enterprises' use of Internet has a significant positive impact on their exports. Specifically, firmsthat use e-mail to communicate with clients and suppliers are $14.5 \%$ more likelyto export andsell $6.68 \%$ more abroad on average than firms that do not usee-mail.This paper further changes the construction of the core explanatory variables to test the robustness of the results, and finds that Internet still plays a significant role in promoting the export of enterprises. In view of the possible endogenous problems caused by selection bias, this paper uses the balanced samples of propensity score matching (PSM) method for regression analysis, and finds that the results are still robust. Finally, wefind that firms with high capacity are more likely both toenter export markets and to be export intensive.Specifically, firms with high-capacity are more $28.1 \%$ likely to export and sell $9.94 \%$ more abroad than firms do not use e-mail, which is a more significant promoting effect than the average effect. 
This paper contributes to three strands of the literature. Firstly, based on the data from the World Bank's EnterpriseSurvey, this paper provides empirical evidence for Internet use to promote the export of enterprises from micro perspective.Secondly, this paper systematically studies the impact of Internet use on the probability and intensity of export of enterprises, exploring this impact qualitatively and quantitatively.Finally, weuse the PSM method to solve the selection bias problem and make the regression results more reliable.

The remainder of this paper is organized as follows. Section 2 reviews the related literature. Section 3 describes the data, variables, and summary statistics. Section 4 presents the main empirical results regarding the effect of Internet use on firm export. Section 5 concludes this paper.

\section{A Brief Review of Relevant Literature}

As a general-purpose technology, the Internet has exerted extensive influence on all fields and levels of society(Harris,1998;Anastasiadis et al. , 2018;Ciruela-Lorenzo et al. , 2020).A large number of literatures have studied the impact of information technology represented by the Internet on production efficiency(Jorgenson et al., 2008; Oliner et al.,2008; Van Ark et al. ,2008), and some scholars have studied the relationship between the Internet and economic growth(Roller \&Waverman, 2001;Czernich et al., 2011; Choi\&Yi, 2009), as well as the relationship between the Internet and product sales and employment(Levin,2011;Stevenson,2008).In particular, the rapid development of the Internet has brought about a huge impact on the development of global trade. And we will summarize the relatedliterature from the theoretical and empirical aspects.

First, from the theoretical level, Internet may promote the export of enterprises by reducing transaction costs.Anderson \&Wincoop (2004) argue that search cost and communication cost are two important and widespread forms of trade costs.Fink et al.(2005) give empirical evidence of the cost of international trade exchanges, and concludes that the higher the cost of bilateral exchanges, the smaller the scale of international trade.Li and $\mathrm{Li}$ (2017) point out that the use of the Internet can reduce the cost of information exchange, especially for long-distance information exchange. These time and financial savings make it more likely that businesses using the Internet will engage in trade, and they will do so more frequently(Sheng et al. ,2011;Ferro,2011;Timmis,2013;Niru,2014; Meijers, 2014; Yushkova, 2014).Venables(2001) also points out that Internet can reduce the cost of organization management, search, match and communication between enterprises and upstream and downstream suppliers, as well as between enterprises and consumers.

Secondly, from the perspective of empirical analysis, the literature analyzes the impact of Internet use on the export of enterprises from both domestic and corporate levels.At the national level,Freund and Weinhold (2004) find that thereis a significant effectof the Internet on trade in recent years based on time-series and cross-section regressions. The results suggest that a $10 \%$ increase in thegrowth of web hosts in a country leads to about a $0.2 \%$ increase in export growth.Lin(2014) uses panel data from nearly 200 countries from 1990 to 2006 to estimate the promotion effect of the Internet on international trade. The results show that every $10 \%$ increase in Internet users will increase the total amount of international trade by $0.2 \%-0.4 \%$.Mallick (2014) uses gravity model to study the impact of infrastructure on the export of goods and services in 48 countries from 2000 to 2010, and finds that the Internet in the technological infrastructure has a greater promoting effect on the service trade.

With the introduction of the hypothesis of heterogeneity into the trade model by the new trade theory represented by Melitz (2003), there are many studies on the impact of Internet on the export of enterprises from the enterprise level.Based on transnational data, Freund \&Weinhold (2004) find that the increase of Internet development would increase the growth rate of the country's export trade.Timmis (2013) finds that the Internet use is beneficial to the direct export of enterprises, but has no significant impact on the indirect export.Niru (2014) studies the impact of the Internet on the export and import of enterprises in Asia and sub-Saharan Africa, and finds that the Internet reduces the cost related to information entering the international market, and the use of email and website has a positive impact on the margin of enterprises' export and import.Ferro (2011) finds that using websites to communicate with customers and suppliers increases the export probability of enterprises by $11 \%$.

It can be seenfrom the summary of the above literature thatthere are abundant studies on the impact of the Internet on the export of enterprises. However, there are few studies on the sample of Chinese enterprises, which is not commensurate with China's status as the largest Internet country in the world ( $\mathrm{Li}$ and $\mathrm{Li}$, 2017).Next we will make a detailed empirical test of the above inferences using the World Bank's Survey Data on Chinese enterprises.

\section{Variables and Data}

\subsection{Sample and Variable Selection}


We use the data from the World Bank's EnterpriseSurvey which includes all available information for Chinese manufacturing firms in 2012. This survey adopts the method of stratified random sampling and contains 2700 private enterprises and 148 state-owned enterprises, covering 25 cities in Chinese manufacturing industry.In addition, with this dataset,it is possibleto identify which firm is exporter as there is information on the proportion of totalsales that are sold both in foreignand domestic markets. It is also possible to control other factors that may affect the export of enterprises with thesurvey containing the basic characteristics of the enterprise, such as its finance, production and operation status, as well as the business environment and other indicators. Owning to the different incentives to export between state-owned enterprises and private enterprises, this article only chooses 2700 private enterprises as the sample.After deleting the missing samples, we finally obtained 1541 sample points.

Firstly, we construct two dependent variablesaccording to the question"In fiscal year 2011, what percentage of this achievement's sales were national sales?" On one hand, the variable DOMESTIC is defined to reflect the proportion of totalsales that are sold in domestic markets, which measures the intensity of export quantitatively.On the other hand, the binary variable EXPORT is defined to measure an enterprise's export behaviorqualitatively. If the domestic sales volume of the product is less than $100 \%$, the value of EXPORT is assigned to 1,otherwise is 0 .

Secondly,wedefine the independent variableEMAIL according to the question "At the present time, does this establishment use E-mail to communicate with clients or suppliers?"If the enterprise uses, the variableEMAILis assigned to 1 , otherwise is 0 .This paper also constructs the variablecustom_ICTto replace the core explanatory variable and test the robustness of the results, which measures the application degree of ICT in the customer relationship. Accordingto the question"To what extent are information and communication technologies (computers, Internet, and software) used to support partner relations, marketing and sales?", the enterprisesanswer from 1 to 5, which means"Never", "Rarely(once in a while)", "Sometimes (few times a month)", "Frequently(few times a week)" and "All the time(Daily)", respectively. The value of custom_ICT is based on the average value of the ICT level applied by the enterprise in partner relations and marketing these two aspects.

This paper also controls a series of other factors that may affect the export of enterprises (Aratoet al, 2016). Firstly, at the firm level, we include the size of the firm as given by the logarithm of the number of formal employees. We also includethe age of the firm and whetherthe firm provides formal training to its workers. And we considerthe output of enterprises, which is expressed by the logarithm of the sales volume of enterprises. Secondly, we control the factors related to the business environment ( Gulzar et al. , 2018; Sial et al. , 2018) .We use the dummy variable INFORMto measurethe competitive relationship between the enterprise and the informal enterprises, which is constructed according to whether the enterprise competes with the non-registered or informal enterprise.And we use the variable CRIMEto measure the degree of obstacle caused by crime and theft to the company's operation,with a value of 0 to 4 , which means "No obstacle", "Minor obstacle", "Moderate obstacle", "Major obstacle" and "Very Severe obstacle", respectively.We also construct the variables UNCERTand COURTS to measure the obstacle caused by political instability or courts, with a value of 0 to 4 , meaning the same as above.

Finally,we usetwo other sets of dummy variables to control city and industry fixed effects, considering that export activities may be concentrated due to industry or regional industrial policies. In addition, the dummy variable $H I G H$ is constructed by whether the natural logarithm of the sales volume of the enterprise is greater than the average level of the sample enterprise.If it is greater than the average level, it is regarded as a high-capacity enterprise, and the variable $H I G H$ is assigned to 1 , otherwise 0 .

\subsection{Descriptive Statistics}

Table 1 is the descriptive statistics of the main variables.As can be seen from Table 1, in terms of the export of enterprises, about $23 \%$ of enterprises export products, and thedomestic sales of products account for $89.1 \%$ of the total sales on average. $86.6 \%$ of enterprises use e-mail to contact customers and suppliers and the level of ICT application in maintaining customer relations is high, with an average value of 3.535. For the control variables, the average age of enterprises is 12.4 years, and $60.9 \%$ of enterprises have competitive relationship with the unregistered or informal enterprises. The average obstacle value caused by crimes is only 0.263 , which means crime has done little to hamper the company's operations.83.5 enterprises provide training for employees. Policy uncertainty hindered $21.4 \%$ of business operations, courts $24.9 \%$. And $47.2 \%$ of the enterprises are high capacity enterprises. 
Table 1. Summary Statistics

\begin{tabular}{llllll}
\hline Variable & Obs & Mean & Std.Dev. & Min & Max \\
\hline export & 1541 & 0.230 & 0.421 & 0 & 1 \\
domestic & 1541 & 89.103 & 25.189 & 0 & 100 \\
email & 1541 & 0.866 & 0.340 & 0 & 1 \\
custom_ICT & 1541 & 3.535 & 1.267 & 1 & 5 \\
output & 1541 & 16.468 & 1.661 & 4.605 & 24.124 \\
age & 1541 & 12.421 & 7.077 & 0 & 84 \\
size & 1541 & 3.960 & 1.316 & 1.386 & 9.210 \\
inform & 1541 & 0.609 & 0.488 & 0 & 1 \\
crime & 1541 & 0.263 & 0.544 & 0 & 4 \\
train & 1541 & 0.835 & 0.372 & 0 & 1 \\
uncert & 1541 & 0.214 & 0.410 & 0 & 1 \\
courts & 1541 & 0.249 & 0.432 & 0 & 1 \\
high & 1541 & 0.472 & 0.499 & 0 & 1 \\
& & & & &
\end{tabular}

\section{Main Findings}

\subsection{The Baseline Model}

We first study the impact of Internet use on the export of enterprises.Considering that the explained variable, EXPORT, is a binary discrete variable, the probit model is used for regression analysis in this paper.The specific settings of the regression model are as follows:

$$
\operatorname{Pr}\left(\text { export }_{i, j, k}=1\right)=\Phi\left(\alpha+\text {-email }_{i, j, k}+\gamma \text { control }_{i, j, k}+\text { city }_{j}+\text { industry }_{k}+\mu_{i, j, k}\right)
$$

Here, $\operatorname{export}_{i, j, k}$ refers to whether the enterprise exports as the explained variable, and $i, j, k$ represent enterprise, city and industry respectively.Email ${ }_{i, j, k}$ refers to whether the enterprise uses the Internet as the core explanatory variable. This paper mainly focuses on the coefficient of the core explanatory variable email $_{i}$. Control $_{i, j, k}$ represents a series of control variables, including OUTPUT, AGE, SIZE, INFORM,CRIME,TRAIN,UNCERT, andCOURTS. City and industry fixed effects are controlledwithcity $y_{j}$ and industry ${ }_{k}$ respectively. And $\mu_{i, j, k}$ refers to the random disturbance term.

Since whether an enterprise exports is a dummy variable, which cannot reflect the intensity of the enterprise's exports, we further use variableDOMESTIC to reflect theintensity of export, as another explained variable. In addition,the percentage of the products in the domestic sales (DOMESTIC) isnon-negative,so weuse the tobit model to estimate the impact of Internet useon the export intensity of enterprises.

Table 2 reports the regression results of the influence of Internet use onenterprises' export.In the regression equation, we controlled a series of variables, such as OUTPUT, AGE, SIZE, whether to train employees or not, and also controlled city and industry fixed effects.Column (1) of Table 2 is the regression result of probit model, which shows that enterprises' use of Internet will increase the probability of enterprises' export by $14.5 \%$.Column (2) is the regression result of tobit model, which shows that enterprises' use of the Internet will reduce the proportion of domestic sales by $6.68 \%$. The above results all indicate that Internet use will promote the export of enterprises. 
Table 2 Baseline Regression Results (Probit and Tobit models)

\begin{tabular}{|c|c|c|}
\hline & $\begin{array}{l}1) \\
\text { export } \\
\text { b/se }\end{array}$ & $\begin{array}{l}(2) \\
\text { domestic } \\
\text { b/se }\end{array}$ \\
\hline email & $\begin{array}{l}0.145 * * * \\
{[0.040]}\end{array}$ & $\begin{array}{l}-6.683 * * * \\
{[1.872]}\end{array}$ \\
\hline output & $\begin{array}{l}0.032 * * * \\
{[0.010]}\end{array}$ & $\begin{array}{l}-0.763 \\
{[0.539]}\end{array}$ \\
\hline age & $\begin{array}{l}0.000 \\
{[0.001]}\end{array}$ & $\begin{array}{l}0.087 \\
{[0.087]}\end{array}$ \\
\hline size & $\begin{array}{l}0.027 * * \\
{[0.012]}\end{array}$ & $\begin{array}{l}-1.291^{*} \\
{[0.712]}\end{array}$ \\
\hline inform & $\begin{array}{l}-0.015 \\
{[0.022]}\end{array}$ & $\begin{array}{l}2.493 * \\
{[1.302]}\end{array}$ \\
\hline crime & $\begin{array}{l}0.028 \\
{[0.020]}\end{array}$ & $\begin{array}{l}-2.289^{*} \\
{[1.202]}\end{array}$ \\
\hline train & $\begin{array}{l}0.061 * \\
{[0.032]}\end{array}$ & $\begin{array}{l}-1.659 \\
{[1.726]}\end{array}$ \\
\hline uncert & $\begin{array}{l}-0.033 \\
{[0.040]}\end{array}$ & $\begin{array}{l}0.680 \\
{[2.276]}\end{array}$ \\
\hline courts & $\begin{array}{l}0.038 \\
{[0.037]}\end{array}$ & $\begin{array}{l}-0.708 \\
{[2.113]}\end{array}$ \\
\hline $\begin{array}{l}\text { Industry } \\
\text { effects }\end{array}$ & yes & yes \\
\hline $\begin{array}{l}\text { City fixed effects } \\
\text { _cons }\end{array}$ & yes & $\begin{array}{l}\text { yes } \\
120.619 * * * \\
{[8.131]}\end{array}$ \\
\hline $\begin{array}{l}\text { / } \\
\text { var(e.national) }\end{array}$ & & $\begin{array}{l}511.085^{* * *} \\
{[18.412]}\end{array}$ \\
\hline$N$ & 1393 & 1541 \\
\hline
\end{tabular}

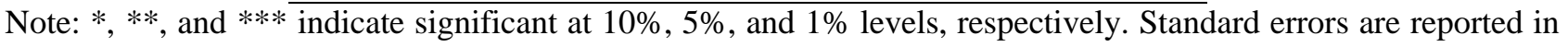
brackets.

\subsection{Robustness Test}

In fact, the variable custom_ICTcan still measure the extent to which an enterprise applies the Internet in terms of customer relationship and marketing, etc. Therefore,in order to verify the robustness of the above regression results, the core explanatory variable EMAIL is replaced by custom_ICT for regression analys. Table 3 reports the regression results. The results show that enterprises' use of the Internet in customer relations still has a significant promoting effect on their export, which is consistent with the previous conclusion. 
Table 3 Robustness Test (Probit and Tobit Models)

\begin{tabular}{lll}
\hline & $\begin{array}{l}(1) \\
\text { export } \\
\text { b/se }\end{array}$ & $\begin{array}{l}(2) \\
\text { domestic } \\
\text { b/se }\end{array}$ \\
\hline \multirow{2}{*}{ custom_ICT } & $0.029 * * *$ & $-0.942^{*}$ \\
output & {$[0.010]$} & {$[0.540]$} \\
& $0.031^{* * *}$ & -0.823 \\
age & {$[0.010]$} & {$[0.542]$} \\
size & 0.000 & 0.094 \\
& {$[0.001]$} & {$[0.087]$} \\
inform & $0.027 * *$ & $-1.291^{*}$ \\
& {$[0.012]$} & {$[0.715]$} \\
crime & -0.017 & $2.586^{* *}$ \\
train & {$[0.022]$} & {$[1.308]$} \\
& 0.027 & $-2.090^{*}$ \\
uncert & {$[0.020]$} & {$[1.205]$} \\
& $0.079 * *$ & -2.296 \\
courts & {$[0.032]$} & {$[1.721]$} \\
& -0.036 & 1.039 \\
Industry fixed effects & {$[0.040]$} & {$[2.280]$} \\
City fixed effects & 0.040 & -1.024 \\
_cons & {$[0.037]$} & {$[2.119]$} \\
& yes & yes \\
\hline I & yes & yes \\
var(e.national) & & $120.222 * * *$ \\
& & {$[8.169]$} \\
\hline$N$ & & $514.297 * * *$ \\
\hline
\end{tabular}

Note: *, **, and $* * *$ indicate significant at $10 \%, 5 \%$, and $1 \%$ levels, respectively. Standard errors are reported in brackets.

\subsection{Endogenous Analysis}

To explore the causal effect of Internet use on corporate exports, we need to address two potential endogenous issues.First, there may be a bias of omitted variable, that is, some unobservable factors in enterprise, market and policy levels will affect whether enterprises use the Internet and export at the same time.In the regression, we try to mitigate the omitted variable bias by controllinga series of variables such as OUTPUT, AGE andSIZE on the level of enterprise, and whether to compete with informal enterprises in the market level, also by controlling the industry and city fixed effectsto reduce the agglomeration effect caused by industrial policies and the industry characteristics.

Second, there may be a problem of selection bias, that is, there is a big difference between the enterprises that use and do not use the Internet.In fact, it can be seen from the above descriptive statistics that only $23 \%$ enterprises exporting products, which are likely to be quite different from most other enterprises that do not export. If we adopt full sample for regression analysis, it is equivalent to use all non-exporting enterprises as the control group, which will make the sample unbalanced. We try to solve this problem by using the PSM method.

The PSM method is a non-parametric estimation method, whose core idea is to select individuals with similar characteristics and conditions from the control group by using the propensity value score (Chen, 2010). Therefore, the first thing is to calculate the propensity score. We take the enterprises that never or rarely use ICT as the control group and the others as the treatment group according to the application degree of ICT in the customer relationship. And all the control variables in the benchmark regression are taken as covariables to calculate the propensity score. Secondly, according to the propensity score value, 1:1 nearest neighbor matching method is adopted for sample matching.After matched, the standardized deviation of all variables is less than $20 \%$, and the results of all $\mathrm{t}$ tests do not reject the null hypothesis that there is no systematic difference between the treatment group and the control group, which indicates 
that our matching results balance the data well, and the comparability between the treatment group and the control group is improved(Rosenbaum \& Rubin,1983; Smith \& Todd,2005; Rosenbaum \&Rubin,1985). Then we use subsamples for the baseline regression analysis.

Table 4 reports the regression results. The result of the column (1) reflects thatthe probability of enterprises to export which use the Internet increase by $16.2 \%$. Column (2) showsthe proportion of domestic sales of products will drop by $4.97 \%$ among enterprises using the Internet. It can be seen from the above results that after we solve the selection bias, Internet use still significantly promotes the enterprises to export.

Table 4 Endogenous analysis (PSM balanced samples, Probit and Tobit models)

\begin{tabular}{|c|c|c|}
\hline & $\begin{array}{l}1) \\
\text { export } \\
\text { b/se }\end{array}$ & $\begin{array}{l}(2) \\
\text { domestic } \\
\text { b/se }\end{array}$ \\
\hline email & $0.162 * * *$ & $-4.971 * *$ \\
\hline output & $\begin{array}{l}{[0.054]} \\
0.041 * * \\
{[0.016]}\end{array}$ & $\begin{array}{l}{[2.135]} \\
-0.964 \\
{[0.695]}\end{array}$ \\
\hline age & $\begin{array}{l}-0.002 \\
{[0.003]}\end{array}$ & $\begin{array}{l}0.120 \\
{[0.134]}\end{array}$ \\
\hline size & $\begin{array}{l}0.019 \\
{[0.022]}\end{array}$ & $\begin{array}{l}-1.412 \\
{[0.995]}\end{array}$ \\
\hline inform & $\begin{array}{l}0.018 \\
{[0.039]}\end{array}$ & $\begin{array}{l}1.486 \\
{[1.912]}\end{array}$ \\
\hline crime & $\begin{array}{l}0.003 \\
{[0.036]}\end{array}$ & $\begin{array}{l}-0.032 \\
{[2.014]}\end{array}$ \\
\hline train & $\begin{array}{l}0.054 \\
{[0.046]}\end{array}$ & $\begin{array}{l}-0.756 \\
{[1.999]}\end{array}$ \\
\hline uncert & $\begin{array}{l}-0.114 \\
{[0.081]}\end{array}$ & $\begin{array}{l}-1.167 \\
{[3.623]}\end{array}$ \\
\hline courts & $\begin{array}{l}0.181 * * \\
{[0.075]}\end{array}$ & $\begin{array}{l}-6.479^{*} \\
{[3.331]}\end{array}$ \\
\hline Industry fixed effects & yes & yes \\
\hline $\begin{array}{l}\text { City fixed effects } \\
\text { _cons }\end{array}$ & yes & $\begin{array}{l}\text { yes } \\
120.967 * * * \\
{[11.232]}\end{array}$ \\
\hline I & & \\
\hline var(e.national) & & $\begin{array}{l}390.053 * * * \\
{[21.737]}\end{array}$ \\
\hline
\end{tabular}
brackets.

Note: *,**, and *** indicate significant at 10\%, 5\%, and 1\% levels, respectively. Standard errors are reported in

\subsection{Heterogeneity Analysis}

According to the new trade theory represented by Melitz(2003), manufacturers' decisions on production and trade mainly depend on their own productivity level, and enterprises need to pay certain fixed costs to enter the international market. These entry costsmight include expenses related to establishing a distribution channel, transport costs, orproduction costs to modify domestic models for foreign tastes (Ferro,2011). Given the variable costs, the level of fixed costs will directly determine whether enterprises choose to export.A series of papers by Bernard and Jensen $(1999,2003,2005)$ find clear evidence that good firms become exporters.Ricci and Trionfetti (2012) investigate the impact of enterprise productivity and network on enterprises' export ability, and find that enterprises with higher productivity are more likely to export and benefit more from foreign network, domestic network and communication network (mailbox and Internet).So it is likely thatInternet use has different effects on the export behavior of enterprises with different capacity. We divide the sample into high and low capacity groups to investigate whether Internet plays a different role in enterprise export. And then the regression analysis is carried out respectively using the two subsamples. 
The regression results are reported in Table 5. The results show that for high-capacity enterprises, Internet usewill increase their export probability by $28.1 \%$, and the proportion of domestic sales of products will decrease by $9.95 \%$, which is a more significant promoting effect than the average effect, and these impactsare both significant at the significance level of $1 \%$.For low-capacity enterprises, Internet use only increases the export probability by $8.3 \%$, resulting in a decrease in the proportion of domestic sales by $4.71 \%$, and the significance of these effect are obviously reduced.The results indicate that the promotion effect of Internet use on the export of enterprises vary with the different capacity of enterprises. Specifically, enterpriseswith high capacity are more likely both toenter export markets and to be export intensive.

Table 5 Heterogeneity analysis (Probit and Tobit models)

\begin{tabular}{|c|c|c|c|c|}
\hline & $\begin{array}{l}\text { (1) } \\
\text { export } \\
\text { High-capacity }\end{array}$ & $\begin{array}{l}\text { (2) } \\
\text { export } \\
\text { Low-capacity }\end{array}$ & $\begin{array}{l}(3) \\
\text { domestic } \\
\text { High-capacity }\end{array}$ & $\begin{array}{l}\text { (4) } \\
\text { domestic } \\
\text { Low-capacity }\end{array}$ \\
\hline email & $\begin{array}{l}0.281 * * * \\
{[0.085]}\end{array}$ & $\begin{array}{l}0.083 * \\
{[0.044]}\end{array}$ & $\begin{array}{l}-9.948 * * * \\
{[3.443]}\end{array}$ & $\begin{array}{l}-4.714 * * \\
{[2.180]}\end{array}$ \\
\hline output & $\begin{array}{l}0.024 \\
{[0.018]}\end{array}$ & $\begin{array}{l}0.043 * * \\
{[0.020]}\end{array}$ & $\begin{array}{l}-0.168 \\
{[0.980]}\end{array}$ & $\begin{array}{l}-1.104 \\
{[0.887]}\end{array}$ \\
\hline age & $\begin{array}{l}0.001 \\
{[0.002]}\end{array}$ & $\begin{array}{l}-0.000 \\
{[0.002]}\end{array}$ & $\begin{array}{l}0.064 \\
{[0.114]}\end{array}$ & $\begin{array}{l}0.165 \\
{[0.133]}\end{array}$ \\
\hline size & $\begin{array}{l}0.006 \\
{[0.019]}\end{array}$ & $\begin{array}{l}0.053 * * * \\
{[0.018]}\end{array}$ & $\begin{array}{l}-0.069 \\
{[1.033]}\end{array}$ & $\begin{array}{l}-2.953 * * * \\
{[1.023]}\end{array}$ \\
\hline inform & $\begin{array}{l}-0.011 \\
{[0.036]}\end{array}$ & $\begin{array}{l}-0.019 \\
{[0.029]}\end{array}$ & $\begin{array}{l}1.889 \\
{[1.936]}\end{array}$ & $\begin{array}{l}2.379 \\
{[1.724]}\end{array}$ \\
\hline crime & $\begin{array}{l}-0.000 \\
{[0.036]}\end{array}$ & $\begin{array}{l}0.036 \\
{[0.024]}\end{array}$ & $\begin{array}{l}-3.267^{*} \\
{[1.983]}\end{array}$ & $\begin{array}{l}-1.799 \\
{[1.458]}\end{array}$ \\
\hline train & $\begin{array}{l}0.052 \\
{[0.062]}\end{array}$ & $\begin{array}{l}0.017 \\
{[0.038]}\end{array}$ & $\begin{array}{l}1.771 \\
{[3.260]}\end{array}$ & $\begin{array}{l}-0.504 \\
{[2.036]}\end{array}$ \\
\hline uncert & $\begin{array}{l}0.018 \\
{[0.061]}\end{array}$ & $\begin{array}{l}-0.093 \\
{[0.057]}\end{array}$ & $\begin{array}{l}-0.325 \\
{[3.293]}\end{array}$ & $\begin{array}{l}1.365 \\
{[3.092]}\end{array}$ \\
\hline courts & $\begin{array}{l}0.028 \\
{[0.057]}\end{array}$ & $\begin{array}{l}0.066 \\
{[0.054]}\end{array}$ & $\begin{array}{l}-2.329 \\
{[3.054]}\end{array}$ & $\begin{array}{l}-0.125 \\
{[2.920]}\end{array}$ \\
\hline $\begin{array}{l}\text { Industry fixed } \\
\text { effects }\end{array}$ & yes & yes & yes & yes \\
\hline $\begin{array}{l}\text { City fixed effects } \\
\text { _cons }\end{array}$ & yes & yes & $\begin{array}{l}\text { yes } \\
109.267 * * * \\
{[17.071]}\end{array}$ & $\begin{array}{l}\text { yes } \\
129.504 * * * \\
{[13.500]}\end{array}$ \\
\hline var(e.national) & & & $\begin{array}{l}522.917 * * * \\
{[27.408]}\end{array}$ & $\begin{array}{l}443.530 * * * \\
{[21.998]}\end{array}$ \\
\hline$N$ & 666 & 668 & 728 & 813 \\
\hline
\end{tabular}
brackets.

Note: *,**, and *** indicate significant at 10\%, 5\%, and 1\% levels, respectively. Standard errors are reported in

\section{Conclusion}

The Internet in China has developed rapidly in recent years, which provides a new, convenient and efficient information communication channels for individuals and businesses. In addition, Internet greatly reduces the cost of information exchange, and Chinese Internet-based economic activities are also showing a trend of rapid growth.A follow-up question is whether the Internet boosts corporate exports? This paper made a systematic study of the impact of Internet use on the export of enterprises using the data of the World Bank's Enterprise Survey in 2012.

The empirical research results of this paper show that enterprises' use of the Internet has a significant positive impact on their exports. Specifically,firmsthat use e-mail to communicate with clients and suppliers are $14.5 \%$ more likelyto export andsell $6.68 \%$ more abroad on average than firms that do not usee-mail.In order to test the robustness of this result, we change the construction method of the core explanatory variables and find that this effect is still significant. Furthermore, in view of the endogenous problem caused by possibleselection bias, this paper uses the balanced samples of PSM method for regression analysis, and finds that the Internet still plays a significant role in promoting the export 
of enterprises. Finally, we find that firms with high capacity are more likely both toenter export markets and to be export intensive. Specifically, firms with high-capacity are more $28.1 \%$ likely to export and sell $9.94 \%$ more abroad than firms do not use e-mail, whichis a more significant promoting effect than the average effect.

\section{References}

Anastasiadis, Foivos; Tsolakis, Naoum; Srai, JagjitS.(2020). Digital Technologies Towards Resource Efficiency in the Agrifood Sector: Key Challenges in Developing Countries.Sustainability, 12,4850.

Anderson, J. and E Wincoop. (2004).Trade Costs.Journal of Economic Literature,42(3), 691-751.

Bernard, Andrew and J. Bradford Jensen. (1999). Exceptional Exporter Performance: Cause, Effect, or Both? . Journal of International Economics, vol. 47, pp. 1-25.

Bernard, Andrew and J. Bradford Jensen.(2004). Exporting and Productivity in theUSA. Oxford Review of Economic Policy, Oxford University Press, vol. 20(3), pp. 343-357.

Bernard, Andrew, Jonathan Eaton, J. Bradford Jensen, and Samuel Kortum.(2003). Plantsand Productivity in International Trade. The American Economic Review, vol. 93(4), pp. 1268-1290.

ChenQiang. (2014). Advanced econometrics and Stata applications.(2nd ed.). Beijing:Higher education press,(Chapter 28).

Choi,C., and M. Yi.(2009).The Effect of Internet on Economic Growth: Evidence from Cross-Country Panel Data. Economics Letters, 105(1),39— 41.

Ciruela-Lorenzo AM, Del-Aguila-Obra AR, Padilla-Meléndez A, Plaza-Angulo JJ. (2020). Digitalization of AgriCooperatives in the Smart Agriculture Context. Proposal of a Digital Diagnosis Tool. Sustainability,12(4),1325.

Czernich,N., O. Falck,T. Krestschmer, and L.Woessmann.(2011). Broadband Infrastructure and Economic Growth. Economic Journal,121(552),505-532.

Ferro, Esteban.Signaling and Technological Marketing Tools for Exporters. (2011).World Bank, Policy Research working paper series,No. 5547,

Fink, C. , A. Mattoo, and C. Neagu. (2005). Assessing the Impact of Communication Costs on International Trade. Journal of International Economics，67(2)，428-445.

Freund, Caroline L. and Diana Weinhold. (2004).The Effect of the Internet ofInternational Trade. Journal of International Economics, vol. 62(1), pp. 171-189.

Gulzar M, Cherian J, Sial MS, Badulescu A, Thu PA, Badulescu D, KhuongNV.(2018). Does Corporate Social Responsibility Influence Corporate Tax Avoidance of Chinese Listed Companies? Sustainability,10(12),4549.

Harris, R. (1998).The Internet as a GPT: Factor Market Implications. In General Purpose Technologies and Economic Growth. MIT Press,145-166.

Jorgenson,D., M. Ho, and J. Stiroh.(2008).A Retrospective Look at the US Productivity Growth Resurgence.Journal of Economic Perspective,22(1),3-24.

Levin,J.The Economics of Internet Market.(2011).NBER Working Paper,No.16852.

Li Bing, Li Rou. (2017). Internet and Firms' Exports: Empirical Evidence from China'sIndustrial Enterprises. The Journal of World Economy,40(07), pp.102-125.

Mallick, Hrushikesh.(2014).Role of Technological Infrastructures in Exports: Evidence from a Cross-Country Analysis. International Review of Applied Economics, 28 (5), pp. 669-694.

Meijers, H. (2014).Does the Internet Generate Economic Growth,International Trade, or Both. International Economics \& Economic Policy,11(1-2),137-163.

Melitz, M . J . (2003). The Impact of Trade on Intra - Industry Reallocations and Aggregate Industry Productivity.Econometrica,71( 6), pp.1695 - 1725.

Niru, Yadav. (2014). The Role of Internet Use on International Trade: Evidence from Asian and Sub-Saharan African Enterprises. Global Economy Journal,14(2), pp. 198-214.

Oliner,S., D. Sichel,and J. Stiroh. (2008). Explaining a Productive Decade. Journal of Policy Model,30(4), 633 - 673.

Ricci, Luca Antonio and Trionfetti, Federico. (2012).Productivity, Networks, and Export Performance: Evidence from a Cross-Country Firm Dataset.Review of International Economics, 20 (3), pp. 552-562.

Roller,L., and L.Waverman. (2001).Telecommunications Infrastructure and Economic Development: A Simultaneous Approach. American Economic Review,91(4),909—923. 
Rosenbaum, Paul R. and Rubin, D. B. (1983).The Central Role of the Propensity Score in Observational Studies for Causal Effects. Biometrika,70 (1), pp. 41-55.

Rosenbaum, Paul R. and Rubin, D. B. (1985).Constructing a Control Group Using Multivariate Matched Sampling Methods That Incorporate the Propensity Score. American Statistician,39 (1), pp. 33-38.

Sheng, Dan, Bao, Qun, and YongjinWang .(2011).The impact of infrastructure on the export behavior of Chinese enterprises: "intensive margin" or "expansion margin". The Journal of World Economy,1st issue.

Sial MS, Zheng C, Khuong NV, Khan T, Usman M.(2018). Does Firm Performance Influence Corporate Social Responsibility Reporting of Chinese Listed Companies? Sustainability, 10(7),2217.

Smith,J. A. and Todd, P. E. (2005). Does Matching Overcome LaLonde's Critique of Nonexperimental Estimators? . Journal of econometrics, 125(1),pp. 305-353.

Stevenson,B. (2008).The Internet and Job Search. NBER Working Paper,No.13886.

Timmis , Jonathan.(2013).Internet Adoption and Firm Exports in Developing Economies. University of Nottingham,GEP, discussion papers.

Van Ark,B., M. Mahony,and P. Timmer. (2008).The Productivity Gap between Europe and the United States: Trends and Causes.Journal of Economic Perspective,22(1), 25- 44.

Venables, A . (2001). Geography and International Inequalities: The Impact of New Technologies.Journal of Industry,Competition and Trade,1(2), 135-159.

Yushkova,E. (2014). Impact of ICT on Trade in Different Technology Groups: Analysis and Implications. International Economics and Economic Policy, 11 (1), 165-177. 